\section{Ten books}

\section{Chosen by Simon Wessely}

Let's be frank. Doctors and scientists don't need to read books. Our colleagues in the humanities use books to communicate - we use papers. Most medical books are poorly written, unless the author happens to be a Richard Dawkins or a Stephen Jay Gould. Some, those tedious multi-author tomes, or worse, conference proceedings, should never have been written at all.

However, all is not gloom. Psychiatrists differ from the rest of our medical and scientific colleagues, in both positive and negative ways. As I made my choices, I was pleasantly reminded that the discovery of the relevance to psychiatry of literature, criticism and history (where books remain the currency of communication) was one reason why I was originally attracted to the subject.

How to choose? I could repeat the example of Elisabeth Schwarzkopf on Desert Island Discs and choose only my own books - but that would leave me with nine empty spaces. Books in which I have appeared? If I was the much missed Robert Cawley, who began this series, I could have included Janet Frame's (2002) An Angel at my Table, in which he is a central, and affectionately drawn, character. But I have only made it into fiction on one occasion, in a Clare Francis novel which I prefer not to recall. So I have followed the convention and introduced a crude chronology, an apologia pro mia vita illustrated by the books I was reading at different periods of my career.

\section{Psychiatry in Dissent}

Previous contributors to this series have paid tribute to those giants of the 1960s Illich, Goffman and Laing - as inspiring the intellectual journeys that led to what would inevitably become a distinguished career in psychiatry. I was not a 'child of the 60 s', but a child in the $60 \mathrm{~s}$, and my distinguished career has yet to happen. I missed the excitement those gurus generated. Instead, my own desire to be a psychiatrist was initiated by a book that was a sober response to the intellectual brilliance, but also excesses, of that decade.
I came across Psychiatry in Dissent (Clare, 1976) when I was a medical student. I was enjoying the struggle to acquire those clinical skills that were so prized by medical students, which would be my passport to a world that seemed divided between Dr Kildare and Sir Lancelot Spratt. However, I had to admit that I found the intellectual, as opposed to the practical and tribal, side of medicine unsatisfying. I had done science subjects at school because I had always wanted to be a doctor, even if I can no longer remember why, but I continued to read literature and history in my spare time. Starting the psychiatry course was a joy, since here were doctors who could talk about ideas and did not dismiss history as something to be done by retired physicians on the verge of Alzheimer's. But what were the ideas? Laing, Goffman, Szasz, Illich \& Co. were still big, but left me doubtful and confused. The problem was that none of those books inspired one to pursue a career in medicine in general, let alone in psychiatry.

It was Anthony Clare who persuaded me that psychiatry was worthwhile after all. On the surface, it was an exposition of the arguments that were convulsing the intellectual community - but underneath it was a firm statement that psychiatry was not quite so damned as Laing and Szasz would have us believe.

And it was a damned good read. Clare made psychiatry legitimate again, while continuing to address issues and concepts that were so much more interesting than those I had encountered so far at medical school. After Psychiatry in Dissent I was convinced that psychiatry was important, interesting and even glamorous (the first two I still believe, the last not). Ideas were as important as the ability to wield a stethoscope. Cardiology seemed to be bereft of genuine intellectual arguments Tony Clare showed that this was not true of psychiatry.

\section{The Art of Psychotherapy}

I left medical school and did my time as a proper doctor, but my commitment to a career in clinical psychiatry remained intact. Naturally, when I arrived for interview at the Maudsley in 1984, I professed to Robin Murray, who was the gatekeeper to the rotation, a passionate commitment to research, but I was lying. I was still deeply in the culture of the medical senior house officer, in which facts and skills were prized, and uncertainty (the necessary precursor to ethical research) seen as weakness. Research was what people did when they should have been teaching me. My greatest triumph was to hear a diastolic murmur, albeit after 5 years of trying. This event fortunately happened 3 days before I sat medical membership, was repeated during the exam itself, and never since. It was not clear where the diastolic murmurs of psychiatry lay, but the relevant skills seemed to include talking to patients, an expertise which I arrogantly thought I possessed until I tried it. Anthony Storr's book (1990), supplemented with large doses of Dennis Brown and Jonathan Pedder's Introduction to Psychotherapy (1979), gave me the basis for making my interactions with troubled patients something more than mere conversation and convinced me that psychiatry is, in its way, no less skilful than swinging a stethoscope and considerably more artful. Rereading it after many years, some of Storr has dated, but the underlying wisdom that both books possess has not dimmed.

\section{Epidemiology for the Uninitiated}

In the Dean's presence, I had sworn allegiance on the altar of research, but for a while my heretical views remained constant, if of necessity private. And then I read Lee Robin's (1978) paper 'Sturdy predictors of adult antisocial behaviour'. And I was hooked - this was research, and it was exciting - clear, clean, coherent and relevant. But what kind of research was it? It was Michael Shepherd who answered that question for me during our one private conversation in the 6 months I was his registrar. The research that had caught my imagination was epidemiology. I had naively thought that epidemiology involved counting things, which was true, but was perhaps the least interesting part of it. Shepherd, realising that my knowledge of epidemiology did not even justify the word rudimentary, pointed me in the direction of Barker's slim collection of BMJ pieces (Coggan et al, 1993). What that showed me was that epidemiology counts, but in 
many different ways. It is about illness in populations, a perspective that I had so far lacked, and it also provided the necessary intellectual tools for addressing fundamental questions on causation that I was starting to ask, but had no idea even how to formulate. In due course, I attended the MSc in Epidemiology at the London School of Hygiene. There I was introduced to more adult material, but I still retain affection for this slim, simple introduction to the subject.

\section{The Female Malady}

Historical works figure prominently in the rest of my choices, since one of the pleasures of psychiatry is that history remains relevant to contemporary practice. The history of cardiology in the 19th century and pharmacists in Georgian England, the subjects of two seminars I have attended recently, are both fascinating in their own right, but I did not detect many lessons for contemporary cardiology or pharmacology. Not so psychiatry. Our debates on deinstitutionalisation, psychopathy and compulsory treatment would be arid indeed without some historical perspective.

In retrospect, the 1980s were the golden years of psychiatric historiography, and among the classics of the period was the seminal feminist account of Victorian psychiatry and beyond by Elaine Showalter (1987), who holds the Chair of English Literature at Princeton, when she is not holding a BBC microphone. I am now privileged to know Elaine well, and never cease to marvel at the breadth and depth of her erudition and sparkle, which are evident in all she writes.

Showalter begins with an exposition of Victorian values. The theme is the contrast between images of the female and male in the development of psychiatric thinking. She compares the theme of particular vulnerability of the female with insanity with the prevailing stereotype of the rational male. The male is to rational thought what the female is to emotion, views propagated by, but certainly not restricted to, a profession that was almost entirely male.

As we return now to our alienist roots, in which the practice of psychiatry is increasingly restricted to the care of those with psychosis, Victorian values are as relevant as ever. It is not true to equate the impact of Darwinian theory on Victorian psychiatry (elegantly dissected by Showalter) with the contemporary impact of the new genetics, as one recent commentator did, but Showalter's analysis of how scientific thinking and advances are refracted and distorted via both the popular view and professional practice of psychiatry remains as relevant as ever.

The Female Malady does not cease with the death of Victoria. In what is perhaps the most influential section of her book, Showalter analyses the impact of the First World War on psychiatric thought and practice. Contemporaries accepted that the War represented a turning point for many aspects of thought and culture, but it was The Female Malady that highlighted the seismic changes within psychiatry that resulted from the flood of shell-shocked and hysterical men returning from the Western Front. It was, says, Showalter, 'not feminism but shell shock that initiated the era of psychiatric modernism'.

The Female Malady shifted the goal posts of writings on psychiatry. Reading it again, I am struck by just how wideranging was her vision. But I don't agree with every passage. Edgar Jones and I (2002) have questioned the centrality of the First, as opposed to the Second, World War in changing psychiatric thought. The soldiers that fought and the doctors that looked after the survivors, were still products of the Edwardian era, deeply rooted in concepts of masculinity and courage. The real lessons of the First World War, namely the inability of most to withstand the pressure of intense, industrialised warfare, irrespective of their character or courage, would not be appreciated until the Second World War. And one of the reasons why, on that occasion, there was less resistance to accepting the psychological impact of intense combat, was the role played by the literature and poetry of disillusionment that gradually came to dominate cultural memories and accounts of the Great War. My next choice is not the best known of the literature inspired by that War, but perhaps it should be.

\section{The Middle Parts of Fortune}

I decided to avoid fiction in my choices, but as this account of one man's experience of the Battle of the Somme is clearly autobiographical (except for the ending, which I won't spoil by recounting it), I have included it anyway.

Frederic Manning was a little known author, largely recognised for his book reviews, who joined the army in 1915.
His post-war career was similarly undistinguished and came to a premature end because of his increasing alcoholism. His reputation rests entirely on The Middle Parts of Fortune (Manning, 1930). Manning served as a private soldier at Ypres and the Somme, and the experiences of his central character, Bourne, are closely based on his own observations.

Most of the war fiction with which we are familiar cannot be divorced from the romantic and even pastoral literary influences of its authors. Think Brooke, Sassoon, Graves or Owen. Manning is diff- erent. For one thing, his language is authentic, and indeed was heavily censored, the original expletives not being restored to the text for over 50 years. Its descriptions of the routines of soldiering, the constant preoccupations with food, sleep and sex, are rarely given their appropriate prominence in other accounts. War in its horrors is ever present and on two occasions takes centre stage, but what is faultlessly conveyed is the tedium of military life, interspersed with periods of seemingly random violence. Hemingway, who probably did know a thing or two, called it the finest novel ever about the experience of war.

\section{Culture of Complaint: The Fraying of America}

I read art history at Cambridge, and later remember the excitement that Robert Hughes, Australian, art critique, historian and cultural commentator, was able to generate in his history of 20th-century art, The Shock of the New (1981). His extended essay, Culture of Complaint (1993) shows his journalistic talents on the wider stage. He begins with an attack on the malign influence of what he refuses to call 'political correctness' (Hughes would no more use a cliché like that than split an infinitive) on art criticism. He pours scorn on those who have linked aesthetic discrimination, which he regards as essential for a healthy culture, with racial or sexual discrimination. Requiring high aesthetic standards for any artistic activity does not promote, as some have claimed, injustice or inaccessibility. Authenticity is not enough. For Hughes 'the self is not the sacred cow of American Culture... we have turned arts education into a system in which no one can fail. In the same spirit, tennis could be shorn of its elitist overtones, you just get rid of the net'. 
Hughes returns to the question of self and self-esteem, and when he argues that the latter should and can be earned, rather than assumed of right, he is setting his sights beyond the world of art. And his flag is planted firmly on our soil when he addresses the current victim culture. Here we, if not Hughes, must tread carefully. Empathy for the plight of victims is one of the most attractive aspects of human nature, and if we in psychiatry do not favour victims, then who will? But Hughes's case is not against victims; it is against the elevation of the status of victimhood. Being a victim conveys no automatic moral authority or insight. Moral authority, like self-esteem, must be earned and is not an automatic sequela of adversity. Too powerful an identification with an identity defined solely by adversity, as happens in the further reaches of the Oprah culture, carries dangers. The problem with assuming the victim role for a prolonged period is that the self becomes defined by what has been done to one, rather than what one is or has achieved.

Hughes's polemics are provocative, but his targets deserve critical scrutiny and his prose is never less than exuberant. It is hard not to applaud when he bemoans the coarsening of public debate and encounters, in which there is endless opportunity to 'unwittingly give, and truculently receive, offence'. He observes with distaste how the intensity with which beliefs are held has become more important than the substance or accuracy of those same views - and that in the intellectual equivalent of Gresham's Law, passionate beliefs can triumph over reasoned ones simply because they are held strongly. In a world of single-issue politics, the more the strident and 'fanatical enlist in the crusade, the more sensible people tend to wash their hands of it'. Hughes reminds us that we need to be equally vociferous in our defence of reason and tolerance.

\section{The Threat and the Glory and The Strange Case of the Spotted Mice}

Robert Hughes made no apology for his defence of high culture as an elitist activity. Peter Medawar made the similar case for science. Medawar was well placed to do so, being a Nobel Laureate as a result of his work on immunology and transplantation. But he was not just a pre-eminent scientist, he was also a remarkably well-read man with a gift for lucid exposition. I can still remember the thrill of reading Medawar's passionate defence of science - 'incomparably the most successful activity human beings have ever engaged upon'. It is a view that has become unfashionable, frequently attacked, but never refuted, and it is in Medawar's writings that one finds evidence not just of the power of science, but of its beauty and elegance. In Medawar's hands, immunology becomes a thing of beauty, although I am afraid that psychoanalysis does not.

Most scientists and doctors write, but few write well. I came to Medawar when I was moonlighting as a journalist, deluding myself that I was more a man of letters than a mere scribbler. Medawar, along with Lewis Thomas, showed me the power of the essay and that I would be well advised to keep my day job.

Medawar was incapable of writing a dull paragraph and was contemptuous of those who did. 'People who write obscurely are either unskilled in writing or up to some mischief', which takes me to my next choice.

\section{Intellectual Impostors}

Alan Sokal is Professor of Physics at New York University. In 1996, he perpetrated a now famous hoax by publishing a paper entitled 'Transgressing the boundaries. Towards a transformative hermeneutics of quantum gravity' in a leading American post-modernist journal known as Social Text (Sokal, 1996). It was gibberish, and meant to be so. Sokal's point was not that all cultural studies and criticism are gibberish (my other choices show that argument to be nonsense), but that some modern intellectuals have taken to using scientific terminology without the slightest knowledge of its real meaning. In Intellectual Impostors (Sokal \& Briemont, 1998) he takes this thesis further, with a stinging series of essays on the abuse of language perpetrated by such cultural luminaries as Kristeva, Latour, Baudrillard (famous for declaring that the Persian Gulf war had not taken place, which if true would have deprived me of the opportunity of being associated with the research that has given me the greatest pride) and finally that old charlatan himself, Jacques Lacan, who draws Sokal's ire not for his pronouncements on psychoanalysis, which to me appear gnomic and impenetrable, but for his woeful misunderstanding and misuse of mathematical and scientific concepts and language - seemingly erudite but actually meaningless. Medawar would have applauded.

\section{'Ordinary Men': Reserve Police Battalion IOI and the Final Solution in Poland}

Tell a taxi driver that you are a psychiatrist and you are likely to be asked 'so why did he do it, doctor?' - the 'he' referring to whichever criminal or celebrity (the two are occasionally and to everyone's unfeigned delight synonymous) is in the news for some misdeed or other. Sadly, my replies often have no more insight than those of the cab driver. If you want to learn the answer to 'why did he do that?' it is better to turn to an historian.

When we consider the history of human misdeeds and their motives, sooner or later we must consider the overwhelming question - why did the civilised Germans organise the greatest crime in history? I have read much on this subject, but nothing excels Christopher Browning's (1992) painstaking analysis of the records and statements of a single German police battalion and their actions on one day in July 1942, when they murdered the Jewish population of Josefow in Poland. Browning is scrupulous in his use of the historical record to guide us through the complexities of belief, background, situation and behaviour that led to the horrors of that event. It is a masterful account of how to construct a narrative from tainted sources, illuminating where possible, but always aware of the limitations of the data. Precisely because he is so careful with his sources, and unwilling to go beyond what can be justified, his conclusions are penetrating. We can never know exactly why this bunch of Hamburg policemen, none of them fanatical Nazis, acted in the way they did, but this is as close as we can get.

The same incident, and the same material, also forms a large section of Daniel Goldhagen's (1997) Hitler's Willing Executioners. Like all Holocaust historians, Goldhagen pays short shrift to those who claim that the perpetrators were coerced into their actions by fear - the commander of the police battalion allowed anyone who wished not to take part in the Aktion to remain in the barracks without censure but beyond that he has little to say. His conclusion is that Germans, such as the Hamburg policemen, killed Jews because they wanted to. Publicly acclaimed, but 
critically damned, his polemical account contains material guaranteed still to shock despite its repugnant familiarity - but the lack of any serious historical analysis means that it remains at the level of reportage and is ultimately unsatisfying. Browning closes with an observation of importance for psychiatry - 'explaining is not excusing understanding is not forgiving'. Neither author forgives, but only one explains.

\section{My Life and Hard Times and The Secret Life of Walter Mitty}

I read My Life and Hard Times (Thurber, 1933) first as a boy. I could never get beyond the first chapter, 'The night the bed fell in', without dissolving into helpless laughter. It was some 20 years before I realised that it was not, in fact, a recollection of Thurber's turn-of-the-century childhood in Columbus, Ohio, but a parody of a genre. I still love it, and as the years go by, I recognise more and more of the episodes as containing more prophecy than parody. Thurber's fictional aunt was played for comic effect by having her believe that electricity leaks out of sockets unless they are covered with metal foil. I have now seen several patients and one Sunday newspaper supplement with the same belief. The grandfather who occasionally leaps out of bed shouting that the Army of the Potomac is doomed, seemingly unable to accept that the Civil War had ended 30 years previously, is a strange forerunner of veterans with Vietnam flashbacks, and 'The day the dam broke' remains a classic account of rumour and panic. But for those who have never encountered Thurber, his genius found its best expression in the perfect comic short story, The Secret Life of Walter Mitty (Thurber, 1945). Walter Mitty is all our secret fantasies, whether it be the intrepid torpedo-boat commander defiant of weather and enemies in equal measure, the attorney saving his client, the surgeon with nerves of steel who repairs the anaesthetic machine with his penknife while operating with the other hand, or finally, the insouciant resistance fighter, facing the firing squad, cigarette in hand, defiant to the last.

Brown, D. \& Pedder, J. (1979) Introduction to Psychotherapy. An Outline of Psychodynamic Principles and Practice. London: Tavistock Publications.

Browning, C. (1992) 'Ordinary Men': Reserve Police Battalion 101 and the Final Solution in Poland. New York: Harper Collins.

Clare, A. (1976) Psychiatry in Dissent. London: Tavistock Publications.

Coggan, D., Rose, G. \& Barker, D. J. P. (eds) (1993) Epidemiology for the Uninitiated (3rd edn). London: BMJ Books.

Frame, J. (2002) An Angel at my Table. London: Women's Press.

Goldhagen, D. (1997) Hitler's Willing Executioners: Ordinary Germans and the Holocaust. London: Abacus.

Hughes, R. (1981) The Shock of the New. New York: Alfred A. Knopf.
- (1993) Culture of Complaint: The Fraying of America. Oxford: Oxford University Press.

Jones, E. \& Wessely, S. (2002) The impact of Total War on the practice of psychiatry. In Shadows of Total War: 1919-1939 (eds R. Chickering \& S. Foerster). Cambridge: Cambridge University Press (in press).

Manning, F. (1930) The Middle Parts of Fortune. Republished 1999 as Her Privates We. London: Serpent's Tail

Medawar, P. (1991) The Threat and the Glory: Reflections on Science and Scientists. Oxford: Oxford University Press.

- (1996) The Strange Case of the Spotted Mice. Oxford: Oxford University Press.

Robins, L. N. (1978) Sturdy childhood predictors of adult antisocial behaviour. Psychological Medicine, 8 , 611-622.

Showalter, E. (1987) The Female Malady: Women, Madness and English Culture, 1830-1980. London: Virago.

Sokal, A. (1996) Transgressing the boundaries. Towards a transformative hermeneutics of quantum gravity. Social Text, 46, 217-230.

— \& Briemont, J. (1998) Intellectual Impostors. London: Profile Books.

Storr, J. (1990) The Art of Psychotherapy (2nd edn) London: Routledge.

Thurber, J. (1933) My Life and Hard Times. New York \& London: Harper \& Bros.

— (1945) The secret life of Walter Mitty. In The Thurber Carnival. London: Hamish Hamilton.

Simon Wessely Department of Psychological Medicine, GKT School of Medicine and Institute of Psychiatry, 103 Denmark Hill, London SE5 8AF, UK. E-mail: s.wessely@iop.kcl.ac.uk 